\title{
TNFRSF14 Gene
}

National Cancer Institute

\section{Source}

National Cancer Institute. INFRSF14 Gene. NCI Thesaurus. Code C97843.

This gene plays a role in receptor signaling. 